\title{
Double Stranded DNA Virus
}

National Cancer Institute

\section{Source}

National Cancer Institute. Double Stranded DNA Virus. NCI Thesaurus. Code C14348.

A virus that has double stranded DNA as its genetic material. 